\title{
First record of Bombus (Alpigenobombus) wurflenii Radoszkowski, 1860 in the Kola Peninsula, NW Russia
}

\author{
Grigory S. Potapor', Yulia S. Kolosova' and Alisa A. Vlasova'
}

\begin{abstract}
Potapov GS, Kolosova YuS and Vlasova AA. 2018. First record of Bombus (Alpigenobombus) wurflenii Radoszkowski, 1860 in the Kola Peninsula, NW Russia. Fauna norvegica 38: 9-12.

In this paper we present the first record of Bombus wurflenii from northern Russia. This species was found in the southwestern part of the Kola Peninsula, near the town of Kandalaksha in 2016. The nearest confirmed record of the species is in northern Sweden. In Russia, B. wurflenii was known earlier but only from southern Ural. The status of the population of $B$. wurflenii in the Kola Peninsula is unknown and needs further research.
\end{abstract}

doi: 10.5324/fn.v38i0.2341. Received: 2017-09-13. Accepted: 2018-01-13. Published online: 2018-01-17. ISSN: $1891-5396$ (electronic).

Keywords: Bombus wurflenii, European North of Russia, Kola Peninsula, fauna.

1. Federal Center for Integrated Arctic Research, Naberezhnaya Severnoy Dviny 23, Arkhangelsk 163000, Russia.

Corresponding author: Grigory S. Potapov

E-mail: grigorij-potapov@yandex.ru

\section{INTRODUCTION}

Bombus (Alpigenobombus) wurflenii Radoszkowski, 1860 is widespread in Europe and is typical of mountain regions of Scandinavia, Central and Eastern Europe, northern Spain, the Balkans, the Caucasus and northern Turkey (Løken 1973; Reinig \& Rasmont 1988; Rasmont \& Iserbyt 2010). There is one old record from northern Finland (Suomussalmi Municipality, Ruhtinansalmi Village, 30.06.1926, leg. O. Sorsakoski) (Söderman \& Leinonen 2003: 286), but it is doubtful, according to the opinions of some authors (Söderman \& Leinonen 2003; Rasmont \& Iserbyt 2010). In Russia, B. wurflenii is only known from southern Ural (Reinig \& Rasmont 1988; Rasmont \& Iserbyt 2010). It is included in the Red Book of the Russian Federation as a species with decreasing number (category 2) (Panfilov \& Berezin 2001).

Until recently, records of $B$. wurflenii from the European North of Russia, and particularly the Kola Peninsula, were not known. Compared with neighbouring regions (northern parts of Finland, Norway and Sweden), the bumblebee fauna of the Kola Peninsula remains insufficiently studied (Potapov et al. 2015). Most of the collected materials have been collected from the coast of the Barents Sea and from the Khibiny Mountains. Particularly, the southern part of the region has been poorly studied. A review of the bumblebee fauna of the Kola Peninsula and other parts of the Murmansk Region is presented by Paukkunen \& Kozlov (2015).

In this paper, we present the first record of B. wurflenii from the Kola Peninsula.

\section{MATERIAL AND METHODS}

Bumblebees were collected in the vicinity of the town of Kandalaksha, which is located in the southwestern part of the Kola Peninsula (Figure 1). Bumblebee individuals were 


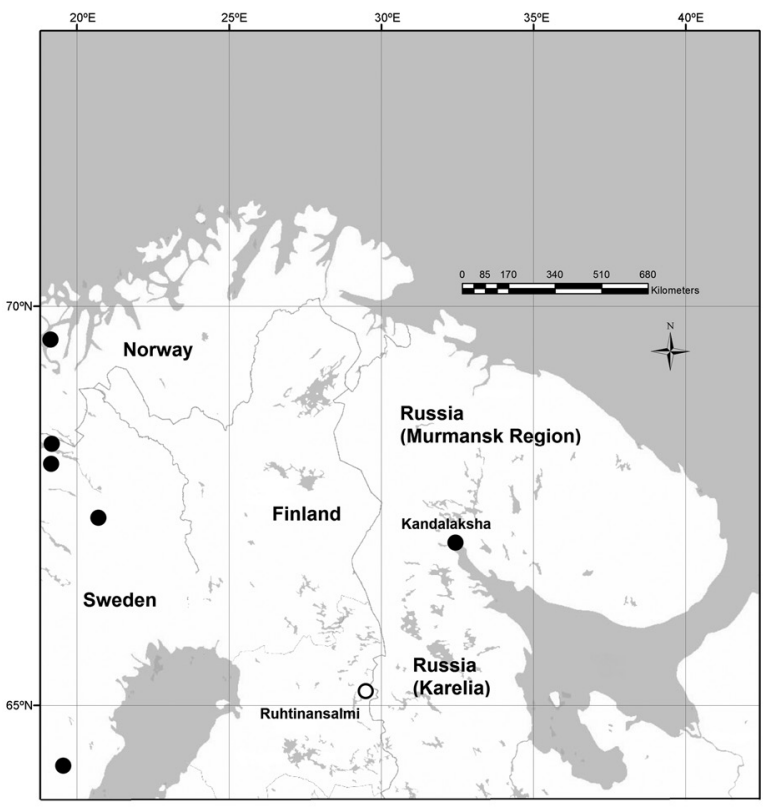

Figure I. Map of the study region. The sampling localities from Kandalaksha (Russia, Murmansk Region) and Scandinavian countries are shown as a black circles. The unverified localities from Ruhtinansalmi (Finland) is shown as an open circle. found near a roadside that runs alongside the coniferous forest $\left(67^{\circ} 08^{\prime} 43^{\prime \prime} \mathrm{N}\right.$; $\left.32^{\circ} 25^{\prime} 55^{\prime \prime} \mathrm{E}\right)$ on the $26^{\text {th }}$ and $28^{\text {th }}$ of July 2016 , and they were caught with an entomological net on Cirsium arvense (L.) Scop. The total number of specimens is 6 . Three individuals are workers and three are males.

Bumblebees were identified by using the key from Løken (1973). The nomenclature follows Williams (2017). Images of the specimens were taken by using a Leica EZ4D stereomicroscope (Leica Microsystems GmbH, Germany).

All specimens are deposited in the Russian Museum of the Biodiversity Hotspots (RMBH), Federal Center for Integrated Arctic Research (FCIARctic), Russian Academy of Sciences (RAS), Arkhangelsk, Russia.

The map in Figure 1 was produced by using ArcGIS 10.0 software (Environmental Systems Research Institute, ESRI ${ }^{\circledR}$ ).

\section{RESULTS}

All of the six specimens of bumblebees belong to B. wurflenii ssp. brevigena Thompson, 1870 (Reinig \& Rasmont 1988; Söderman \& Leinonen 2003). General views of specimens of worker and male with its genital capsule are shown in Figure 2. This subspecies is dark coloured, while females have black
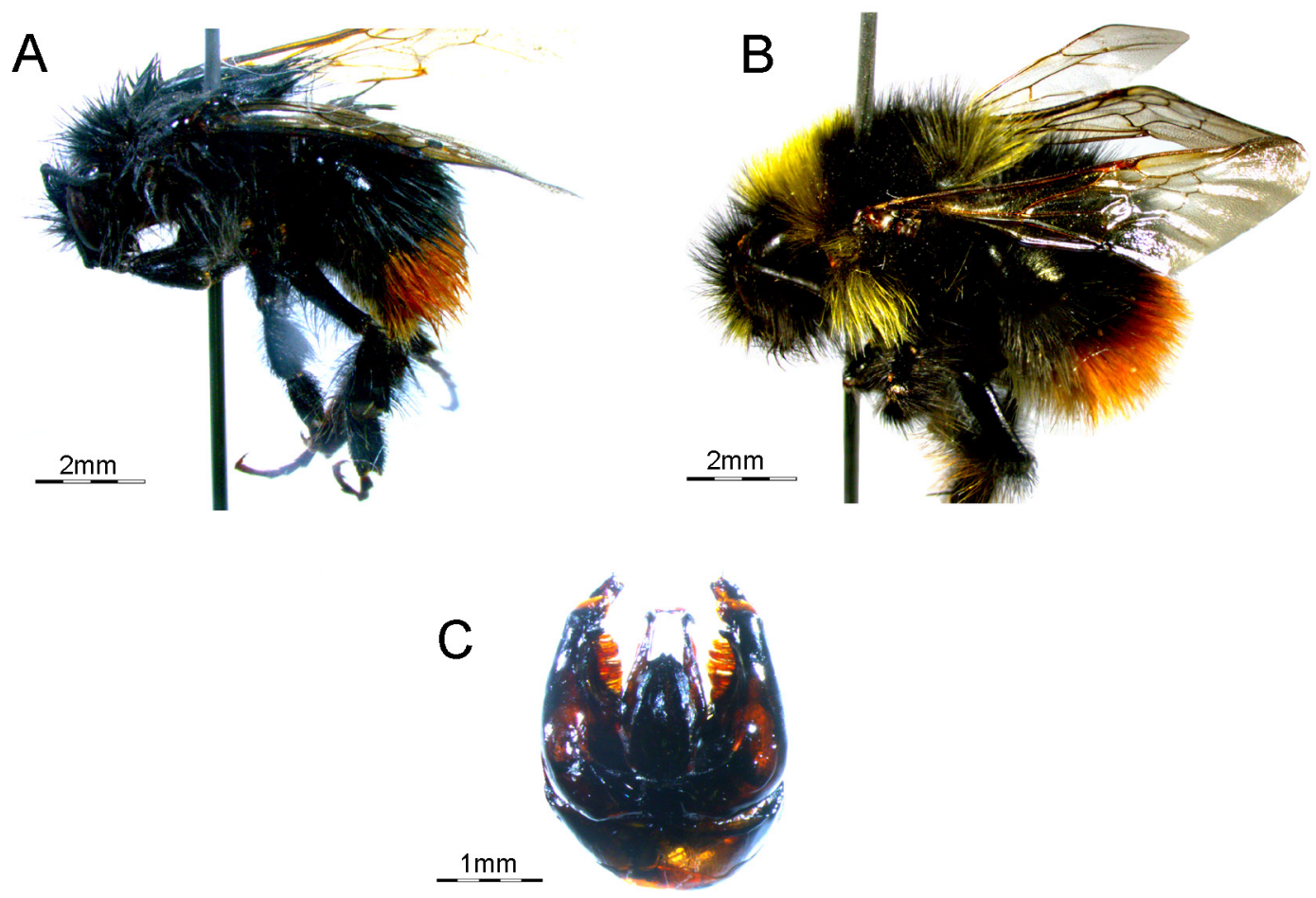

Figure 2. Morphological patterns of the studied specimens of Bombus wurflenii: general view of worker (a), male (b), and genital capsule (c). Photo: Grigory Potapov. 
thorax and black three first tergites with very slight admixture of yellow hairs (Løken 1973; Reinig \& Rasmont 1988). This subspecies inhabits Scandinavia. The nominate subspecies occurs in the Caucasus and northern Turkey (Reinig \& Rasmont 1988).

\section{DISCUSSION}

To the best of our knowledge, our finding of $B$. wurflenii is the first for northern Russia. In the Kola Peninsula and other parts of the Murmansk Region, this species has not been recorded earlier (Paukkunen \& Kozlov 2015; Potapov 2015). This species has not been found in other regions of northern Russia, i.e. either Karelia or Arkhangelsk Region (Söderman \& Leinonen 2003; Potapov \& Kolosova 2016). The nearest confirmed record of $B$. wurflenii has been made in northern Sweden (Rasmont \& Iserbyt 2010).

If we assume that B. wurflenii appeared in the Kola Peninsula recently, the possible migratory pathways of this species can pass from northern Sweden and Norway through northern Finland. On the other hand, there is a possibility that the species has been overlooked in the Murmansk Region. It is noteworthy that the colouration of workers of $B$. wurflenii bears some resemblance to B. lapidarius L., 1758, and the colouration of males of this species bears some resemblance to $B$. pratorum L., 1761. However, B. lapidarius is unknown from the Murmansk Region and northern Karelia (Rasmont \& Iserbyt 2010). B. pratorum and B. wurflenii have distinctly different male genitalia (Løken 1973), hence it is unlikely that these species would be wrongly identified. Some authors, who based their findings on large collections and summarised the materials of the bumblebee fauna for the different districts of the Murmansk Region, have never recorded $B$. wurflenii in the region (Potapov 2015; Paukkunen \& Kozlov 2015). It is more likely that the finding of $B$. wurflenii is caused by insufficient knowledge of the bumblebee fauna in the Murmansk Region.

In support of the first assumption, it is noteworthy that in recent decades some bumblebee species have expanded their distribution northwards in Fennoscandia (Martinet et al. 2015). With respect to B. lapidarius (Linnaeus, 1758) and $B$. terrestris (Linnaeus, 1758), both species dispersed to the North above latitude $68^{\circ} \mathrm{N}$ (Martinet et al. 2015). Also, B. wurflenii has expanded its distribution in Scandinavia, and "now occurs $200 \mathrm{~km}$ north of its 1973 limits", which is above latitude $69^{\circ} \mathrm{N}$ (Martinet et al. 2015: 305). The eastwards expansion of $B$. wurflenii is also quite possible. According to the models of the suitable areas for $B$. wurflenii with respect to the future (Rasmont et al. 2015), the areas adjacent to the Kola Peninsula can be considered as future areas of occurrence for this species.

Further research is necessary in order to assess the status of the population of $B$. wurflenii in the Kola Peninsula and adjacent areas.

\section{ACKNOWLEDGEMENTS}

This study was supported by the Russian Foundation for Basic Research (RFBR, project no. 16-34-60035 mol_a_dk). We are grateful to Juho Paukkunen M.Sc. (Finnish Museum of Natural History, University of Helsinki, Finland) for providing us with valuable information concerning Bombus wurflenii in Finland. Special thanks are due to Dr. Matthew Copley for improving the language.

\section{REFERENCES}

Løken A. 1973. Studies of Scandinavian bumblebees (Hymenoptera, Apidae). Norsk Entomologisk Tidsskrift 20(1): 1-218.

Martinet B, Rasmont P, Cederberg B, Evrard D, Ødegaard F, Paukkunen J, Lecocq T. 2015. Forward to the north: two EuroMediterranean bumblebee species now cross the Arctic Circle. Annales de la Société entomologique de France (N.S.) 51 (4): 303-309. doi: 10.1080/00379271.2015.1118357

Panfilov DV, Berezin MV. 2001. Bombus mastrucatus Gerstaecker, 1869. In: Red Book of the Russian Federation (animals). Moscow. Ministry of Natural Resources and Environment of the Russian Federation. http://www.mnr.gov.ru/regulatory/detail. php?ID=128273. Accessed 2017-12-05

Paukkunen J, Kozlov MV. 2015. Stinging wasps, ants and bees (Hymenoptera: Aculeata) of the Murmansk region, Northwest Russia. Entomologica Fennica 26: 53-73.

Potapov GS. 2015. Structure of bumblebee communities (Hymenoptera: Apidae, Bombus Latr.) in the European North of Russia. PhD thesis. Tomsk. National Research Tomsk State University. 147 p. (In Russian).

Potapov GS, Kolosova YuS. 2016. Fauna of bumblebees (Hymenoptera: Apidae: Bombus Latr.) in the mainland part of Arkhangelsk Region, NW Russia. Annales de la Société entomologique de France (N.S.) 52 (3): 150-160. doi: 10.1080/00379271.2016.1217167

Potapov GS, Kolosova YS, Kondakov AV. 2015. Bumblebee assemblages (Hymenoptera, Apidae) of ruderal habitats in the Kola Peninsula, NW Russia. Fauna norvegica 35: 3-8. doi: 10.5324/fn.v35i0.1837

Rasmont P, Iserbyt S. 2010. Atlas of the European Bees: genus Bombus. 3rd Edition. STEP Project. Atlas Hymenoptera. http:// zoologie.umons.ac.be/hymenoptera/page.asp?ID=169. Accessed 2017-12-05

Rasmont P, Franzén M, Lecocq T, Harpke A, Roberts SPM, Biesmeijer JC, Castro L, Cederberg B, Dvořák L, Fitzpatrick U, Gonseth Y, Haubruge E, Mahé G, Manino A, Michez D, Neumayer J, Ødegaard F, Paukkunen J, Pawlikowski T, Potts SG, Reemer M, Settele J, Straka J, Schweiger O. 2015. Climatic risk and distribution atlas of European bumblebees. Biorisk 10 (Special issue).

Reinig WF, Rasmont P. 1988. Beitrag zur Kenntnis der Bergwaldhummel Alpigenobombus wurfleini (Radoszkowski, 1859). Spixiana 11(1): 37-67.

Söderman G, Leinonen R. 2003. Suomen mesipistiäiset ja niiden uhanalaisuus. Helsinki. Tremex Press. 420 p. 
Williams PH. 2017. Bumblebees of the World. London. Natural History Museum. http://www.nhm.ac.uk/research-curation/ projects/bombus/index.html. Accessed 2017-12-05.

Editorial responsibility: Torkild Bakken.

This article is open-access and distributed under the terms of the Creative Commons Attribution 4.0 International license. This permits all non-commercial use, distribution, and reproduction in any medium, provided the original work is properly cited.

(http://creativecommons.org/licenses/by/4.0/). 